\title{
Problematika Manajemen Kesiswaan, Personalia dan Humas Beserta Pemecahan Masalahnya di Sekolah Dasar ( Studi Riset di SD Intis School Yogyakarta) \\ Permana Octofrezi \\ STAI Masjid Syuhada Yogyakarta
}

\begin{abstract}
Student management problems, personnel and public relations problems and their problem solving in elementary schools (Research Study at SD INTIS School Yogyakarta). The purpose of this research is to find out the concepts, roles and problems that occur in student management, personnel and community relations at school basic. In addition the authors provide solutions or problem solving for problems that occur. The method the researcher used was a descriptive qualitative research method with data sources through interviews with relevant school leaders. The results showed that the problems that occur in student management include: 1) Some students are inconsistent in following an extracurricular activity and tend to ask to move to another extracurricular, 2) the committee is less loyal to their duties, 3) the problem of uniforming student administration, 4) the number of agendas that are lacking supported by sufficient funds, 5) the existence of extracurriculars that are less effective and devoid of interest. In personnel management, the following problems were found: 1) there are those who have resigned annually, 2) the lack of training and development of human resources for educators and education staff. Whereas in public relations management problems are found: 1) Lack of staff or or limited human resources in the field of Public Relations, 2) In carrying out their duties and functions, Public Relations Employees lack expertise (competence), 3) Overlapping of work with one another, 4) Not having an adequate budget, 5) Sometimes the funds that have been budgeted turn out to be incompatible with reality on the ground. So that inevitably the public relations staff sometimes pack all the needs in accordance with what is budgeted.
\end{abstract}

Keywords: Management of education, Students, Personnel, Public Relations 


\section{Pendahuluan}

Sebuah institusi atau lembaga pendidikan akan berlangsung dan berkembang pesat jika dikelola oleh manajemen yang tertata apik. Manajemen yang rapi, teratur, dan terencana akan mempengaruhi kinerja, kualitas dan eksistensi sebuah lembaga pendidikan. Manajemen ini dikomandoi oleh kepala sekolah selaku manajer dalam semua manajemen pendidikan di sekolah. Kepala sekolah membentuk kepengurusan dibawah kepemimpinannya yaitu Para Wakil Kepala (disingkat Waka) setiap ruang lingkup manajemen yang ada mulai dari Wakil Kepala Kesiswaan (Wakasis), Wakil Kepala Kurikulum (Wakakur), Wakil Kepala Sarana dan Prasarana (Waka Sarpras), Wakil Kepala Humas (Waka Humas), dan staf-staf lainnya yang berhubungan.

Dalam pandangan Islam, sebagai muslim yang baik kita harus mampu memanage waktu. Segala urusan dari bangun tidur sampai tidur lagi harus tertata, rapi, benar, tertib, dan teratur. Proses-prosesnya harus diikuti dengan baik, tidak boleh dikerjakan secara asal-asalan. Arah tujuan pekerjaan yang jelas dan landasan yang kuat serta cara-cara mendapatkannya yang transparan akan menjadikan amal perbuatan yang diberkahi dan diridhoi Allah swt. Hal ini merupakan prinsip utama dalam ajaran Islam. Sesuai dengan prinsip itu, maka manajemen dalam arti mengatur segala sesuatu agar dilakukan dengan baik, tepat dan tuntas merupakan hal yang disyariatkan dalam ajaran Islam.

Parameter keberhasilan dalam mutu pendidikan bergantung kepada manajemen yang dikelola oleh suatu lembaga pendidikan Islam (sekolah/madrasah) yang bersangkutan. Manajemen tersebut akan efektif dan efisien dan relevan jika didukung oleh sumber daya manusia yang professional dan berkompeten memanajerial lembaga tersebut, Waka Kurikulum yang mengelola kurikulum yang sesuai dengan tingkat perkembangan dan karakteristik siswa, kepala bagian personalia yang memiliki kompetensi dan komitmen, Waka Sarpras yang mampu mengelola sarana-prasarana yang memadai untuk mendukung kegiatan belajar-mengajar, Waka Keuangan yang mengelola dana dan berinisiatif menganggarkan dana yang cukup serta memberi gaji staf sesuai dengan jabatannya.

Apabila salah satu saja dari hal-hal di atas tidak sesuai dengan yang diharapkan atau tidak berfungsi sebagaimana mestinya, maka relevansi, efektifitas dan efisiensi pengelolaan lembaga tersebut kurang optimal. Dalam implementasinya disuatu lembaga pendidikan, manajemen pendidikan tidak bisa berjalan sebagaimana mestinya tanpa manajerial dari personil-personilnya 
yang melaksanakan tugas secara profesional dan maksimal dan memberi kontribusi segenap jiwa dan keterampilannya untuk kepentingan lembaga, serta meningkatkan produktifitas kerjanya dari hari ke hari, Hal ini harus didukung oleh optimalisasi dari kerja manajemen lain yang saling bahu membahu mengembangkan dan mewujudkan tujuan lembaganya.

Selama me-manage ataupun mengelola manajemen pendidikan sekolah tentu dihadapi dengan berbagai problematika yang dilalui oleh pelaku manajemen. Dalam penelitian kali ini, penulis tertarik mengadakan penelitian manajemen pendidikan dan problematikanya di SD International Islamic School (disingkat SD INTIS School) yang berlokasi di Kotagede Yogyakarta. Adapun ruang lingkup manajemen pendidikan yang dibahas khusus disini adalah manajemen kesiswaan, manajemen personalia, dan manajemen hubungan mastarakat (humas). Secara lebih detail akan dirincikan dibawah ini :

1. Manajemen Kesiswaan, Pengertian dan Ruang Lingkupnya

Dalam manajemen organisasi sekolah, sebelum pergantian tahun ajaran baru biasanya ada pembentukan pengurus ataupun pergantian pengurus sekolah yang dipilih dari para pendidik (dewan guru) yang pada akhirnya dibuat struktur. Dalam keterangan struktur ada garis putus-putus dan garis koordinasi yang menggambarkan hubungan koordinasi antar pengurus. Dari struktur inilah manajemen pendidikan diatur dan dikelola. Struktur terdiri dari kepala sekolah selaku manajer utama dalam manajemen pendidikan di sekolah.

Manajemen Kesiswaan meliputi pengaturan, penataan maupun pengelolaan peserta didik dan segala hal yang berkaitan dengan peserta didik mulai dari input (masuk) dan output (keluaran) peserta didik di suatu sekolah. Manajemen Kesiswaan memiliki 3 (tiga) tugas utama yakni penerimaan peserta didik baru (PPDB), kegiatan kemajuan belajar dan pembinaan kedisiplinan peserta didik. ${ }^{214}$

Para pakar pendidikan banyak yang memakai sebutan lain dalam manajemen kesiswaan, ada yang menyebut dengan istilah manajemen peserta didik, adapula yang menyebut dengan istilah manajemen murid. Istilah-istilah tersebut memiliki makna yang sama yakni "siswa/murid/peserta

214 Mulyasa, Manajemen Berbasis Sekolah, Konsep Strategi dan Implementasi (Bandung : PT Remaja Rosdakarya, 2003), hal. 46.

ÁL-FÂHIM | Vol I No. 2, September 2019 
didik" sebagai objek dari manajemen. Tujuan dari manajemen ini adalah terwujudnya keteraturan, kelancaran dan ketertiban dalam kegiatan-kegiatan siswa dan kegiatan proses pembelajaran yang berlangsung baik dari perencanaan, penerimaan sampai siswa tersebut menamatkan pendidikan di suatu sekolah. ${ }^{215}$

Siswa merupakan input dalam suatu lembaga pendidikan (sekolah/madrasah). Sedangkan keberhasilan suatu pendidikan dapat dilihat atau dipandang melalui output yang dihasilkannya. Input yang bermutu sebanding dengan Output yang bermutu pula. Output yang mempunyai mutu atau kualitas yang tinggi tidak mungkin dihasilkan dari input yang rendah. Output yang tinggi biasanya dihasilkan melalui input yang tinggi pula. Jika suatu lembaga ingin mendapat output yang baik maka inputnya pun harus bibit-bibit yang baik pula. Oleh karena itu sudah seyogyanya suatu lembaga (sekolah/madrasah) yang ingin meningkatkan kualitas pendidikannya harus meningkatkan kualitas inputnya dahulu supaya outputnya berkualitas pula.

Secara garis besar, ruang lingkup dari manajemen kesiswaan meliputi :

a. Perencanaan Kesiswaan

b. Penerimaan Peserta Didik Baru (PPDB)

c. Pengklasifikasian/Pengelompokan siswa

d. Orientasi siswa baru

e. Kehadiran siswa

f. Pembinaan kedisiplinan siswa

g. Pembinaan kedisiplinan siswa

h. Layanan siswa

i. Program Ekstrakurikuler

j. Organisasi siswa

Organisasi Siswa Intra Sekolah (OSIS) merupakan wadah organisasi siswa yang bisa menampung aspirasi dan penyaluran kegiatan yang sesuai dengan minat bakat siswa di luar kurikulum. Melalui OSIS siswa bisa berlatih kepemimpinan, belajar berorganisasi dan dapat melaksanakan semua kegiatan dengan teratur dan tertib di bawah pengawasan kepala sekolah dan pembinaan guru.

215 Baharuddin dan Moh. Makin, Manajemen Pendidikan Islam, Transformasi menuju sekolah/madrasah unggul (Malang : UIN-Maliki Press, 2010), hal. 67 
Tim pakar Universitas Negeri Malang mengidentifikasi beberapa ruang lingkup manajemen kesiswaan sebagai berikut ${ }^{216}$ :

a. Perencanaan peserta didik, termasuk di dalamnya adalah school census, school size, dan effective class

b. Penerimaan peserta didik, meliputi penentuan kebijakan penerimaan peserta didik, sistem penerimaan peserta didik, kriteria penerimaan peserta didik, prosedur penerimaan peserta didik, pemecahan problem-problem penerimaan peserta didik.

c. Orientasi peserta didik baru, meliputi pengaturan-pengaturan antara lain : hari-hari pertama peserta didik di sekolah/madrasah, pekan orientasi peserta didik, pendekatan yang digunakan dalam orientasi peserta didik dan teknikteknik orientasi peserta didik

d. Mengatur kehadiran dan ketidakhadiran peserta didik di sekolah/madrasah. Termasuk di dalamnya adalah peserta didik yang membolos, terlambat datang dan meninggalkan sekolah/madrasah sebelum waktunya.

e. Mengatur pengelompokan peserta didik, baik yang berdasarkan fungsi persamaan maupun berdasarkan fungsi perbedaan

f. Mengatur evaluasi peserta didik, baik dalam rangka memperbaiki proses belajar-mengajar, bimbingan dan penyuluhan maupun untuk kepentingan promosi peserta didik.

g. Mengatur kenaikan tingkat peserta didik

h. Mengatur peserta didik yang mutasi dan drop out

i. Mengatur kode etik, pengadilan dan peningkatan kedisiplinan peserta didik

j. Mengatur layanan pendidikan peserta didik

k. Mengatur organisasi peserta didik

2. Manajemen Personalia, Pengertian dan Ruang Lingkupnya

Manajemen Personil atau Personalia adalah segenap proses penataan yang bersangkut-paut dengan masalah memperoleh dan menggunakan tenaga kerja untuk dan di sekolah dengan efisien, demi tercapainya tujuan sekolah yang

216 Ibid., hal. 71

ÁL-FÂHIM | Vol I No. 2, September 2019 
ditentukan sebelumnya. ${ }^{217}$ Segenap proses penataan yang dimaksud adalah :

a. Merencanakan kebutuhan pegawai

b. Penarikan, nilai dari mengumumkan kebutuhan pegawai menyeleksi (reqruitment)

c. Penempatan (placement) sesuai dengan formasi

d. Menggunakan tenaga kerja termasuk merangsang gairah kerja dengan menciptakan kondisi-kondisi atau suasana kerja yang baik

e. Memelihara kesejahteraan pegawai berupa gaji, insentif, hari libur dan cuti, pertemuan-pertemuan yang bersifat kekeluargaan dan bentuk-bentuk kesejahteraan yang lain.

f. Mengatur kenaikan pangkat dan kenaikan gaji yang lain

g. Meningkatkan mutu pegawai baik melalui pendidikan maupun kesempatan-kesempatan lain misalnya mengikuti pendidikan (service training), penataran, diskusi ilmiah, lokakarya, langganan majalah dan surat kabar, menjadi anggota perkumpulan profesi dan lain sebagainya

h. Mengadakan penilaian terhadap prestasi kerja pegawai untuk memperoleh data dalam rangka peningkatan pangkat pegawai

i. Menata pemutusan hubungan kerja dengan pegawai. ${ }^{218}$

Personalia adalah semua anggota organisasi yang bekerja untuk kepentingan organisasi yaitu untuk mencapai tujuan yang sudah ditentukan. Personalia organisasi pendidikan mencakup para guru, pegawai, dan para wakil siswa atau mahasiswa. Termasuk juga para manajer pendidikan yang mungkin dipegang oleh beberapa guru.

Personalia ini ditangani oleh para pimpinan (manager) agar aktifitas mereka dapat dipertahankan dan semakin meningkat. Para manajer akan membina mereka, berusaha mewujudkan antar hubungan yang baik, menilai dan mempromosikan mereka dan berupaya meningkatkan kesejahteraan mereka. ${ }^{219}$

Manajemen tenaga kependidikan (guru dan personil) mencakup tujuh komponen, yaitu :

a. Perencanaan pegawai

b. Pengadaan pegawai

217 Suharsimi Arikunto dan Lia Yuliana, Manajemen Pendidikan (Yogyakarta : Graha Cendekia bekerja sama dengan Pujangga Press, Tanpa tahun), Hal. 105. 218 Ibid., Hal. 106

219 Made Pidarta, Manajemen Pendidikan Indonesia (Jakarta: Rineka Cipta: 2004). Hal. 108 
c. Pembinaan dan pengembangan pegawai

d. Promosi dan mutasi

e. Pemberhentian pegawai

f. Kompensasi

g. Penilaian pegawai.

Ketujuh komponen ini dilaksanakan secara tertib, urut, dan berkesinambungan sehingga harus melalui tahapan-tahapan yang sudah ditentukan. Tahapan awal menjadi prasyarat bagi tahapan kedua, sedangkan tahapan kedua menjadi prasyarat bagi tahapan ketiga dan begitu selanjutnya. ${ }^{220}$

Manajemen personalia memiliki tujuan tertentu yang berorientasi pada optimalisasinya sistem kerja dalam lembaga pendidikan. E. Mulyasa mengatakan bahwa manajemen personalia atau tenaga kependidikan bertujuan untuk mendaya gunakan tenaga kependidikan secara efektif dan efisien guna mencapai hasil yang optimal, namun dengan tetap dalam kondisi yang menyenangkan. Tujuan tersebut mengupayakan adanya kesinambungan antara proses bekerja dengan situasi kerja. Pendayagunaan tenaga kependidikan secara efektif dan efisien tersebut merupakan pemanfaatan tenaga sehingga bisa bekerja secara maksimal dan produktif sekaligus menekan pemborosan.

Pendayagunaan ini tidak bersifat memaksa fisik, tetapi lebih merupakan strategi kerja yang tetap mempertimbangkan unsur-unsur manusiawi. Apalagi, tenaga kependidikan tersebut tetaplah manusia yang tidak bisa disamakan dengan mesin, sehingga membutuhkan sentuhan-sentuhan rohani yang menyenangkan tersebut bisa meringankan beban kerja. ${ }^{221}$

3. Manajemen Humas, Pengertian dan Ruang Lingkupnya

Membahas tentang humas atau dengan memakai istilah lain yakni Public Relation (PR), tentu ingatan kita tertuju pada segala sesuatu yang berhubungan dengan informasi, komunikasi, konferensi pers dan public relation. Bahasa lainnya adalah suatu proses penyampaian segala informasi dan sosialisasi informasi. Menurut Glennand Denny Griswold, Humas merupakan fungsi manajemen yang diadakan untuk menilai dan menyimpulkansikap-sikap publik, menyesuaikan policy dan prosedur instansi atau organisasi dengan kepentingan umum,

220 Mujamil Qomar, Manajemen Pendidikan Islam ( Jakarta : Erlangga, 2007), hal. 131

221 Ibid., hal.129-130

ÁL-FÂHIM | Vol I No. 2, September 2019 
menjalankan suatu program untuk mendapatkan pengertian dan dukungan masyarakat. ${ }^{222}$

Hubungan sekolah dengan masyarakat meliputi beberapa hal sebagai berikut 223 :

a. Mengatur hubungan sekolah dengan orangtua siswa

b. Memelihara hubungan baik dengan Badan Pembantu Penyelenggara Pendidikan (BP3)

c. Memelihara dan mengembangkan hubungan sekolah dengan lembaga-lembaga pemerintah, swasta, dan organisasi sosial

d. Memberi pengertian kepada masyarakat tentang fungsi sekolah, melalui bermacam-macam teknik komunikasi (majalah, surat kabar, mendatangkan sumber)

Sedangkan pengertian Manajemen Humas dalam Pendidikan adalah Rangkaian pengelolaan yang berkaitan dengan kegiatan hubungan lembaga pendidikan dengan masyarakat (orang tua siswa) untuk menunjang kegiatan proses belajar mengajar di sebuah lembaga pendidikan.

Humas itu sendiri memiliki tujuan untuk memajukan kualitas pembelajaran dan pertumbuhan anak, memperkokoh tujuan serta meningkatkan kualitas hidup dan penghidupan masyarakat, serta menggairahkan masyarakat untuk menjalin hubungan dengan sekolah.

Hubungan sekolah dengan masyarakat pada hakikatnya merupakan suatu sarana yang sangat berperan dalam membina dan mengembangkan pertumbuhan pribadi peserta didik di sekolah. Sekolah berkewajiban untuk memberi penerangan tentang tujuan-tujuan, program program, kebutuhan serta keadaan masyarakat. Dan sekolah juga harus mengetahui dengan jelas apa kebutuhan, harapan, dan tuntunan masyarakat, terutama terhadap sekolah. Dengan demikian antara sekolah dan masyarakat harus dibina suatu hubungan yang harmonis. ${ }^{224}$

Hubungan yang harmonis ini akan membentuk :

1. Saling pengertian antara sekolah, orang tua, masyarakat dan lembaga-lembaga lain yang ada di masyarakat, termasuk dunia kerja hal. 154.

222 Suryosubroto, Manajemen Pendidikan di Sekolah (Jakarta : Rineka Cipta, 2010),

223 Ibid., hal. 160.

224 Muhammad Rohman, Sofan Amri, Manajemen pendidikan (Jakarta : PT

Prestasi Pustkaraya, 2012) hal.272 
2. Saling membantu antara sekolah dan masyarakat karena mengetahui manfaat arti dan pentingnya peranan masingmasing

3. Kerjasama yang erat antara sekolah dengan berbagai pihak yang ada di masyarakat dan mereka merasa ikut bertanggung jawab atas suksesnya pendidikan sekolah

Apabila hubungan sekolah dengan masyarakat dapat berjalan dengan baik, harmonis, sering koordinasi, adanya rasa tanggung jawab dan partisipasi masyarakat untuk memajukan sekolah juga akan baik pula. Agar tercipta hubungan dan kerja sama yang baik antara sekolah dan masyarakat, masyarakat perlu mengetahui dengan baik tentang sekolah tersebut.

Pihak sekolah terutama humas sebaiknya banyak memberikan informasi kepada masyarakat tentang programprogram sekolah dan masalah yang dihadapi, sehingga masyarakat tahu dan harapannya masyarakat merasa memiliki dan siap membantu mengatasi masalah-masalah di sekolah. Dengan pemahaman ini, terjadi adanya umpan balik yang sangat berguna bagi pengembangan program sekolah lebih lanjut dan diharapkan pula tumbuhnya rasa simpati masyarakat terhadap program-program sekolah, yang dapat mengundang partisipasi yang aktif masyarakat.

4. Profil SD INTIS School Yogyakarta

SD INTIS School Yogyakarta merupakan sekolah islam swasta dibawah naungan Yayasan Baituttanwir. Sekolah ini berlokasi di Jalan Retno Dumilah No. 54, Kelurahan Rejowinangun, Kecamatan Kotagede Yogyakarta. Lokasi strategis di dekat lokasi wisata kebun binatang Gembira Loka Yogyakarta, wisata kerajinan perak Kotagede, pusat oleh-oleh, XT Square dan lain sebagainya. Sekolah ini mengadakan kegiatan belajar mengajar selma lima hari full. dari hari senin sampai dengan jumat.

SD INTIS School Yogyakarta, berawal dari International Islamic School Yogyakarta, yang memang awalnya bertujuan untuk menciptakan generasi islam yang kuat yang bisa bersaing pada era global. Menjadi sekolah yang boleh dikatakan berbeda dengan sekolah SD pada umumnya seperti SD Negeri, SD Muhammadiyah, SDIT, dan SD lainya menjadi sorotan tersendiri bagi orang tua.

Di Indonesia masih jarang ada SD yang berani mengangkat dua hal besar yaitu International dan islamic, dua hal yang dirasa menjawab tantangan masa depan. Tindakan Pemerintah yang menghapus sekolah internasional dan Rintisan Sekolah Bertaraf 
Internasional (RSBI) menjadikan nama International Islamic School Yogyakarta berubah hanya menjadi SD INTIS School Yogyakarta. Alhamdulllah, karena izin nama sekolah sebelumnya menggunakan SD INTIS School Yogyakarta sehingga tidak terjadi masalah sebagaimana yang terjadi pada sekolah-sekolah bertaraaf internasional.

Seiring berjalanya waktu, SD Intis School Yogyakarta Alhamdulillah semakin berkembang dan semakin banyak diminati dengan beberapa keunggulan dan fasilitas yang ada. Dari segi akademik SD INTIS School Yogyakarta di tahun 2015 mampu menembus peringkat 16 dari 170 sekolah yang ada di Kota Yogyakarta. Hal ini merupakan sebuah pencapaian yang luar biasa dari SD INTIS School Yogyakarta sebagimana yang disampaiakn oleh Ibu Kepala UPT TK/SD Wilayah Yogyakarta Timur, Ibu Dra. Sudaryaryati saat memberi sambutan pada acara Farewell Party 2015 di Gedung XT Square Yogyakarta.

Dengan 8 keunggulan dan program-program yang ditawarkan, sekolah tidak hanya mengambangkan anak dari sisi akademik, tetapi sekolah mencoba memberikan inovasi kurikulum yang bisa mewadahi bakat dan minat anak. Berbagai ekstrakurikuler dijadikan sebagai penunjang pencurahan minat dan bakan anak. Berbagai ajang kompetensi di berbagai bidang pun diikuti dan mampu memperoleh juara seperti spelling bee, menggambar, mewarnai, karate, dana masih banya lagi. Berbagai piala pun terus dikoleksi dengan semakain banyaknya anak yang berprestasi di bidang masing-masing. Program-program yang ditawarkan terus diukur ketercapaian dan terus dievaluasi. Dengan penambahan dan pengembangan sekolah baik dari segi program, target, fasilitas dan peningkatan kualitas SDM melalui berbagai pelatihan, harapan ke depan bisa memberikan pelayanan terbaik dan pencapaian terbaik.

Islamic and Bilingual School, adalah slogan SD INTIS School Yogyakarta yang diambil dari 8 keunggulan yang ada yaitu Islamic and comfortable learning environment, Certified ISO 9001 : 2008, Billingual school, Small class, Brain Gym therapy, Multiple Intelegence aplicaation, Experiental and active learning methode and My City is My Class. ${ }^{225}$

225 Profil SD INTIS School. Dari website http://intisschoolyogyakarta.sch.id 144

ÁL-FÂHIM | Jurnal Manajemen Pendidikan Islam 


\section{Rumusan Masalah}

Dari beberapa uraian di atas, maka permasalahan yang terkait dengan penelitian ini dapat diidentifikasikan sebagai berikut:

1. Bagaimana pengertian dan ruang lingkup manajemen kesiswaan, personalia dan humas di sekolah?

2. Apa saja problematika dalam manajemen kesiswaan, personalia dan humas (studi kasus di SD INTIS School Yogyakarta)?

3. Bagaimana pemecahan masalah dalam manajemen kesiswaan, personalia dan humas (studi kasus di SD INTIS School Yogyakarta)?

\section{Metode Penelitian}

Berikut ini metode penelitian yang penulis rincikan mulai dari jenis penelitian, pendekatan penelitian, metode penetuan subyek, metode pengumpulan data, dan metode analisis data.

1. Jenis Penelitian

Penelitian ini dikategorikan pada jenis penelitian lapangan (Field Research) yang bersifat kualitatif. Penelitian kualitatif yaitu suatu penelitian yang ditujukan untuk mendeskripsikan dan menganalisis fenomena, peristiwa, aktivitas sosial, sikap, kepercayaan, persepsi, pemikiran orang secara individu maupun kelompok. ${ }^{226}$ Menurut Bogdan dan Taylor, metode penelitian kualitatif adalah prosedur penelitian yang menghasilkan data deskriptif berupa kata-kata tertulis atau lisan dari orang-orang dan perilaku yang diamati. ${ }^{227}$

2. Pendekatan Penelitian

Pendekatan yang digunakan dalam penelitian ini adalah pendekatan kualitatif deskriptif. Maksudnya, dalam penelitian kualitatif data yang dikumpulkan bukan berupa angka-angka melainkan data tersebut berasal dari naskah wawancara, catatan lapangan, dokumentasi pribadi, catatan memo, dan dokumen resmi lainnya.228 Sehingga yang menjadi tujuan dalam penelitian ini adalah ingin menggambarkan realitas empirik dibalik fenomena yang ada secara mendalam, rinci dan tuntas. ${ }^{229}$

3. Metode penentuan subyek

${ }^{226}$ Nana Syaodah Sukamdinata, Metode Penelitian Pendidikan, (Bandung : PT Remaja Rosdakarya, 2008), hal. 60.

227 Lexy J. Moleong, Metodologi Penelitian Kualitatif, (Bandung : PT Remaja Rosdakarya, 2007), hal. 4.

228 Mardalis, Metodologi Penelitian Suatu Pendekatan Proposal (Jakarta : Bumi Aksara, 2008), 24.

${ }^{229}$ Moleong, Metodologi Penelitian Kualitatif, hal. 14.

ÁL-FÂHIM | Vol I No. 2, September 2019 
Subyek atau Informan adalah orang-orang yang berhubungan langsung dalam memberikan informasi tentang situasi dan kondisi latar atau obyek penelitian.230 Adapun subjek yang menjadi sumber data dalam penelitian ini adalah :
a. Kepala Sekolah
b. Wakil Kepala Kesiswaan
c. Wakil Kepala Humas (Kepala KTU)

Sedangkan yang menjadi objek penelitian adalah penelitian Penerapan Manajemen Kesiswaan, Personalia dan Humas beserta Problematikanya di SD INTIS School Yogyakarta.

4. Metode pengumpulan data

Untuk memperoleh data yang diharapkan dalam penelitian ini, maka metode pengumpulan data yang digunakan adalah Metode Observasi dan Metode Wawancara. Metode observasi digunakan untuk mendapatkan data tentang letak geografis lokasi sekolah. Sedangkan metode wawancara digunakan untuk mendapatkan data pelaksanaan manajemen kesiswaan, personalia dan humas dari sumber data (informan). Tehnik pengumpulan data dengan mengajukan pertanyaan langsung oleh pewawancara kepada responden. Penulis dalam penelitian ini menggunakan wawancara bebas terpimpin, yaitu komunikasi antara interview bebas dan interview terpimpin yang pelaksanaannya dengan membawa pedoman berupa garis besar tentang hal-hal yang akan ditanyakan. Dalam wawancara ini penulis ingin menggali penerapan Manajemen Kesiswaan, Personalia dan Humas beserta Problematikanya di SD INTIS School Yogyakarta.

5. Metode analisis data

Menurut Bogdan, analisis data adalah proses mencari dan menyusun secara sistematis data yang diperoleh dari hasil wawancara, catatan lapangan, dan bahan-bahan lain, sehingga dapat mudah dipahami dan temuannya dapat diinformasikan kepada orang lain. ${ }^{231}$

Untuk menganalisa data hasil penelitian digunakan metode deskriptif kualitatif, yaitu setelah semua data yang diperlukan telah terkumpul kemudian disusun dan diklasifikasikan,

$230 \mathrm{Ibid}, 132$.

231 Sugiyono, Metode Penelitian Pendidikan, Pendekatan Kuantitatif, Kualitatif, dan RED, Cet. VII (Bandung : Alfabeta, , 2009), 334. 
selanjutnya dianalisa dan diinterpretasikan dengan kata-kata sedemikian rupa untuk menggambarkan obyek penelitian saat dilakukan penelitian, sehingga dapat diambil kesimpulan yang sistematis dan logis.

Metode analisis data yang digunakan dalam penelitian ini adalah analisis kualitatif dengan menggunakan penalaran induktif. Penalaran induktif merupakan cara berpikir yang berangkat dari fakta-fakta khusus, yang kemudian peristiwaperistiwa yang konkrit dan khusus itu ditarik generalisasigeneralisasi yang mempunyai sifat umum. Langkah-langkah proses analisis data dapat dilakukan dengan melaui proses reduksi data, penyajian data, dan menarik kesimpulan.

\section{A. Problematika manajemen Kesiswaan}

Berikut ini adalah paparan problematika yang terjadi ketika penulis melakukan mini riset di Sekolah Dasar International Islamic School Kotagede Yogyakarta berdasarkan wawancara dengan Wakil Kepala (Waka Kesiswaan) ${ }^{232}$ :

1. Pada ekstrakurikuler, beberapa siswa tidak konsisten mengikuti suatu ekskul. Ada beberapa siswa yang tidak betah dan minta pindah ke ekstra kurikuler yang lain. Padahal kalau mau pindah, ketentuannya harus menyelesaikan satu semester dulu.

2. Dari segi kegiatan, ketika ada kepanitiaan, tidak banyak panitia yang turut aktif dan sibuk, yang lain harus di dorong, ditegur baru mau bergerak. Kegiatan yang sudah menjadi kegiatan rutin mingguan juga terkadang penanggung jawabnya kurang sadar akan tugasnya dan cenderung kurang loyal dalam menjalankan tugasnya tersebut.

3. Dari segi administrasi, pengurus harus menyeragamkan administrasi tahun yang lalu yang dikelola oleh pengurus lama dengan administrasi tahun sekarang yang dikelola oleh pengurus yang baru. Perbedaannya terletak pada penyesuaian kegiatan pertahunnya apa. Hal yang sulit adalah terkadang setiap divisi mengganti administrasi kesiswaan tidak sama dengan tahun lalu. Saat di-cek sampai akhir tidak sesuai atau bisa juga lupa mencatatnya.

4. Banyaknya agenda kegiatan kesiswaan yang bervariasi dan seabreg yang kurang ditunjang oleh pendanaan yang cukup dan

232 Hasil wawancara dengan Wakil kepala sekolah divisi Kesiswaan, SD Intis School, Mrs. Febriana Puspasari, S.Pd, 04 April 2015, pukul 11.39 
fasilitas yang memadai. Bahkan panitia harus mencari dana keluar dikarenakan anggaran yang terbatas.

5. Ada beberapa ekskul yang berjalan kurang efektif dan "sepi peminat" , sehingga terpaksa ekskul tersebut tidak dilanjutkan.

Dari permasalahan di atas, maka penulis memberikan alternatif dalam memecahkan masalah pada manajemen kesiswaan tersebut melalui tabel berikut ini :

Tabel 1

Problematika dan pemecahan masalah pada manajemen kesiswaan di SD INTIS School Yogyakarta

\begin{tabular}{|c|c|c|c|}
\hline No. & Problematika Kesiswaan & & Pemecahan Masalah \\
\hline 1 & $\begin{array}{l}\text { Ketika ekskul, ada } \\
\text { beberapa siswa yang tidak } \\
\text { betah dan minta pindah ke } \\
\text { ekstra kurikuler yang lain. } \\
\text { Padahal kalau mau pindah } \\
\text { ekskul, ketentuannya harus } \\
\text { menyelesaikan satu } \\
\text { semester dulu. }\end{array}$ & a. & $\begin{array}{l}\text { Waka kesiswaan } \\
\text { membuat kebijakan dan } \\
\text { peraturan bahwa siswa } \\
\text { tidak diperkenankan } \\
\text { pindah ke ekskul lain } \\
\text { sampai satu semester } \\
\text { berakhir. Peraturan ini } \\
\text { disosialisasikan ke siswa } \\
\text { dan orangtua } \\
\text { Waka membagikan surat } \\
\text { edaran pilihan ekskul } \\
\text { yang berisi formulir } \\
\text { pemilihan ekskul, } \\
\text { peraturan-peraturan } \\
\text { maupun ketentuan ekskul } \\
\text { yang ditandatangani oleh } \\
\text { wali siswa. }\end{array}$ \\
\hline 2 & $\begin{array}{l}\text { Dari segi kegiatan, ketika } \\
\text { ada kepanitiaan, tidak } \\
\text { banyak panitia yang turut } \\
\text { aktif dan sibuk, yang lain } \\
\text { harus di dorong, ditegur } \\
\text { baru mau bergerak. } \\
\text { Kegiatan yang sudah } \\
\text { menjadi kegiatan rutin } \\
\text { mingguan juga terkadang } \\
\text { penanggung jawabnya } \\
\text { kurang sadar akan } \\
\text { tugasnya dan cenderung }\end{array}$ & & $\begin{array}{lr}\text { Perlu dibuatkan } & \text { target } \\
\text { maupun capaian } & \text { setiap } \\
\text { program kerja kesiswaan } \\
\text { pada } & \text { setiap } \\
\text { PJ/Koordinator } & \text { yang } \\
\text { ditunjuk. } & \\
\text { Adanya monitoring dan } \\
\text { evaluasi oleh } & \text { Waka } \\
\text { Kesiswaan dan } & \text { Kepala } \\
\text { Sekolah atas } & \text { kinerja } \\
\text { PJ/Koordinator } & \text { yang } \\
\text { dipercayai melaksanakan }\end{array}$ \\
\hline
\end{tabular}




\begin{tabular}{|c|c|c|c|}
\hline & $\begin{array}{l}\text { kurang loyal } \begin{array}{l}\text { dalam } \\
\text { menjalankan } \\
\text { tersebut. }\end{array} \\
\text { tugasnya }\end{array}$ & & 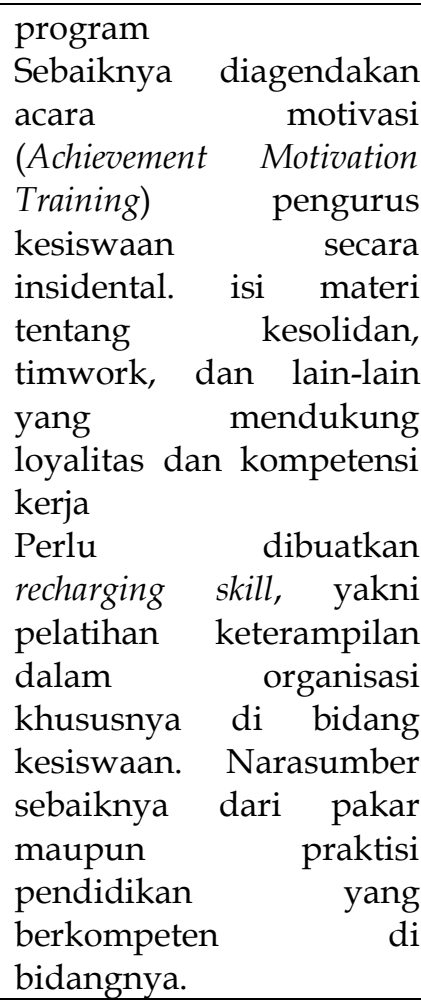 \\
\hline 3 & $\begin{array}{l}\text { Dari segi administrasi, } \\
\text { pengurus } \\
\text { menyeragamkan } \\
\text { administrasi tahun yang } \\
\text { lalu yang dikelola oleh } \\
\text { pengurus lama dengan } \\
\text { administrasi tahun } \\
\text { sekarang yang dikelola } \\
\text { oleh pengurus yang baru. } \\
\text { Perbedaannya terletak } \\
\text { pada penyesuaian kegiatan } \\
\text { pertahunnya apa. Hal yang } \\
\text { sulit adalah terkadang } \\
\text { setiap divisi mengganti } \\
\text { administrasi kesiswaan } \\
\text { tidak sama dengan tahun } \\
\text { lalu. Saat di-cek sampai } \\
\text { akhir tidak sesuai atau bisa } \\
\text { juga lupa mencatatnya. }\end{array}$ & & 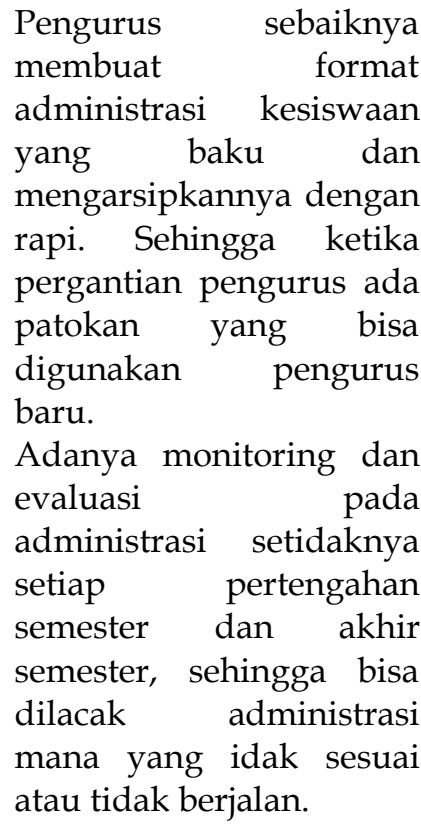 \\
\hline
\end{tabular}




\begin{tabular}{|c|c|c|c|}
\hline 4 & $\begin{array}{l}\text { Banyaknya agenda } \\
\text { kegiatan kesiswaan yang } \\
\text { bervariasi dan se-abreg yang } \\
\text { kurang ditunjang oleh } \\
\text { pendanaan yang cukup dan } \\
\text { fasilitas yang memadai. } \\
\text { Bahkan panitia harus } \\
\text { mencari dana keluar } \\
\text { dikarenakan anggaran } \\
\text { yang terbatas. }\end{array}$ & b. & 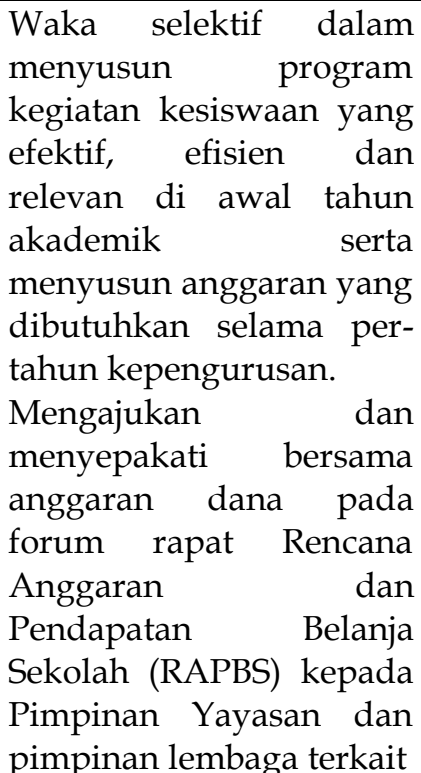 \\
\hline 5 & $\begin{array}{l}\text { Ada beberapa ekskul yang } \\
\text { berjalan kurang efektif dan } \\
\text { "sepi peminat", sehingga } \\
\text { terpaksa ekskul tersebut } \\
\text { tidak dilanjutkan. }\end{array}$ & & 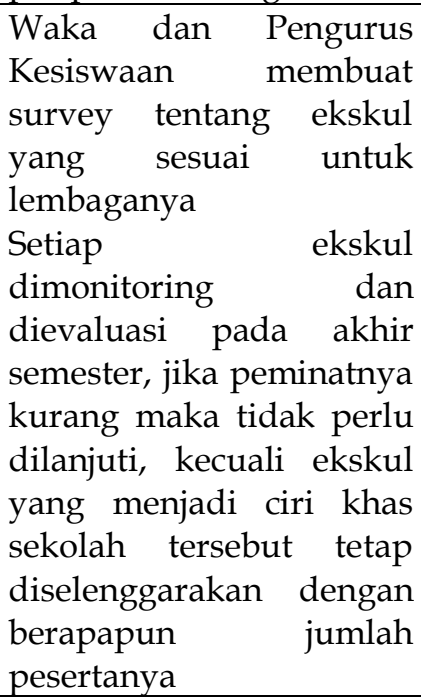 \\
\hline
\end{tabular}

B. Problematika Manajemen Personil

Berikut problematika manajemen personil yang terjadi di Sekolah Dasar International Islamic School Kotagede Yogyakarta ${ }^{233}$ :

1. Rekrutmen dan loyalitas pendidik dan tenaga kependidikan

${ }^{233}$ Hasil wawancara dengan Mr. Sahlan, S.Pd, selaku kepala sekolah SD Intis School Yogyakarta, 04 April 2015, pukul 12.40 
Tenaga pendidik setiap tahunnya ada yang resign (mengundurkan diri), sehingga sekolah terus menyaring dan merekrut tenaga pendidik baru. Untuk mengikatnya, manajemen personalia memberikan peraturan kontrak kerja selama dua tahun ketika tenaga pendidik baru itu diterima dengan jaminan ijazah asli. Sehingga loyalitasnya tetap dipertahankan setidaknya selama kontrak habis.

2. Pembinaan dan Pengembangan SDM (softskill) pendidik dan tenaga kependidikan

Kurang berjalannya pembinaaan dan pengembangan SDM bagi pendidik dan tenaga kependidikan dikarenakan padatnya aktifitas sekolah yang full day school sehingga sulit untuk mencari waktu dan menjadikannya sebagai rutinitas. Hanya beberapa program saja yang berjalan, sedangkan program lainnya bersifat insidental, atau sewaktu-waktu, ketika ada kebutuhan.

Tabel 2

Problematika dan alternatif pemecahan masalah pada manajemen personalia di SD INTIS School Yogyakarta

\begin{tabular}{|c|c|c|}
\hline No. & Problematika Personalia & Pemecahan Masalah \\
\hline 1 & $\begin{array}{l}\text { Tenaga pendidik setiap } \\
\text { tahunnya ada yang resign } \\
\text { (mengundurkan diri), } \\
\text { sehingga sekolah terus } \\
\text { menyaring dan merekrut } \\
\text { tenaga pendidik baru. } \\
\text { Untuk mengikatnya, } \\
\text { manajemen personalia } \\
\text { memberikan peraturan } \\
\text { kontrak kerja selama dua } \\
\text { tahun ketika tenaga } \\
\text { pendidik baru itu diterima } \\
\text { dengan jaminan ijazah asli. } \\
\text { Sehingga loyalitasnya tetap } \\
\text { dipertahankan setidaknya }\end{array}$ & $\begin{array}{l}\text { a. Perlu dibuatkan surat } \\
\text { perjanjian kerja di awal } \\
\text { untuk guru (pendidik) dan } \\
\text { tenaga kependidikan } \\
\text { (karyawan) } \\
\text { b. Perlu dibuatkan SK Kepala } \\
\text { Sekolah dan SK Yayasan } \\
\text { setiap pergantian tahun } \\
\text { akademik kembuat buku } \\
\text { c. Sekolah memberaian } \\
\text { peraturan kepegawain } \\
\text { yang berisi ketentuan- } \\
\text { ketentuan dalam bekerja, } \\
\text { misalkan ketentuan cuti, } \\
\text { izin ketidakhadiran, hak } \\
\text { dan kewajiban dan lain- } \\
\text { lain sehingga buku ini bisa } \\
\text { dibaca dan dijadikan } \\
\text { panduan bagi pendidik } \\
\text { dan tenaga kependidikan }\end{array}$ \\
\hline
\end{tabular}




\begin{tabular}{|c|c|c|}
\hline & selama kontrak habis. & \\
\hline 2 & $\begin{array}{l}\text { Pembinaan } \\
\text { Pengembangan dan } \\
\text { (softskill) pendidik dan } \\
\text { tenaga kependidikan. } \\
\text { Kurang berjalannya } \\
\text { pembinaaan dan } \\
\text { pengembangan SDM bagi } \\
\text { pendidik dan tenaga } \\
\text { kependidikan dikarenakan } \\
\text { padatnya aktifitas sekolah } \\
\text { yang full day school sehingga } \\
\text { sulit untuk mencari waktu } \\
\text { dan menjadikannya sebgaia } \\
\text { rutinitas. Hanya beberapa } \\
\text { program saja yang berjalan, } \\
\text { sedangkan program lainnya } \\
\text { bersifat insidental, atau } \\
\text { sewaktu-waktu, ketika ada } \\
\text { kebutuhan. }\end{array}$ & 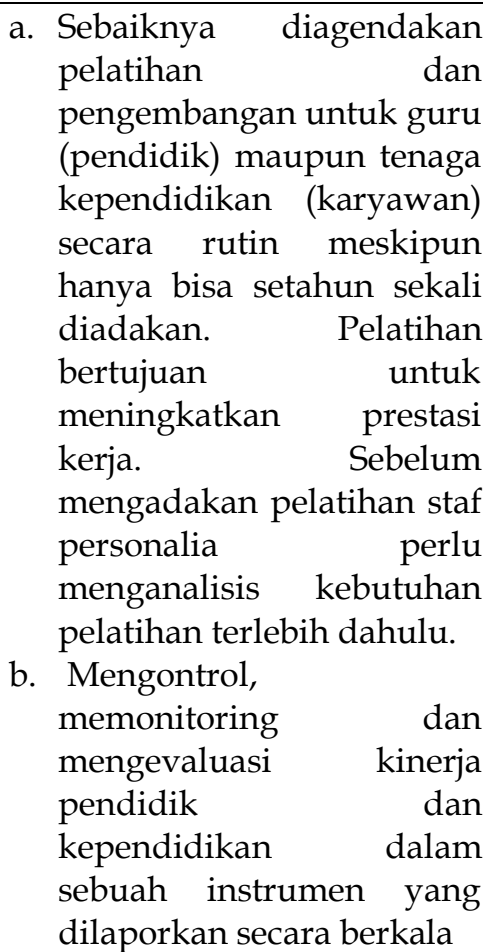 \\
\hline
\end{tabular}

C. Problematika Manajemen Humas

Untuk mengetahui contoh-contoh problematika yang terjadi dalam manajemen humas, maka Penulis mengambil problematika yang terjadi secara umum, dan ditambah problematika yang ada di SD. Penulis mewawancarai salah satu pengurus bagian Humas di Sekolah Dasar Intis School, Kotagede, Yogyakarta.

Adapun beberapa problematika ataupun kendala yang terjadi antara lain sebagai berikut :

1. Kurangnya jumlah tenaga atau atau terbatasnya tenaga SDM di bidang Humas. ${ }^{234}$ Selama ini tenaga Humas masih dipegang satu orang saja yaitu Mr. Ahmad Fathoni, SE. Dari hasil wawancara, beliau mengemukakan bahwa beliau mengurusi semua program yang berhubungan dengan Humas.

2. Dalam menjalankan tugas dan fungsinya, Pegawai Humas kurang memiliki keahlian (kompetensi). Maka perlu pelatihan

234 Wawancara dengan Mr. Ahmad Fathoni, SE, kepala Humas SD Intis School Yogyakarta. 
tenaga kehumasan atau tenaga kependidikan secara berkala, meliputi pelatihan menjadi tenaga humas yang ideal dan profesional, pelatihan praktis di dunia kerja, dan lain-lain, pendidikan tidak linier (lulusan prodi ekonomi).

3. Tumpang tindihnya pekerjaan yang satu dengan lainnya

Hal ini disebabkan tugas Humas yang merangkap tugas kebersihan, dan administrasi. Jadi programnya tidak terfokus di Humas saja. Tapi selama ini Humas tidak mengalami kesulitan untuk menjalani itu semua dengan membagi waktu dan membawahi petugas kebersihan.

4. Tidak memiliki anggaran yang memadai.

5. Terkadang dana yang sudah dianggarkan ternyata tidak sesuai dengan realita di lapangan. Sehingga mau tidak mau Humas terkadang mengemas semua kebutuhan sesuai dengan yang dianggarkan saja. Jika ada realita anggaran kurang, bisa disiasati dengan mengambil alokasi sisa anggaran kebutuhan lain, dengan sistem silang, yakni sisa anggaran lain dipakai untuk menutupi kekurangan yang ada.

Tabel 3

Problematika dan alternatif pemecahan masalah pada manajemen humas di SD INTIS School Yogyakarta

\begin{tabular}{|c|c|c|}
\hline No. & Problematika & Pemecahan Masalah \\
\hline 1 & $\begin{array}{l}\text { Kurangnya jumlah tenaga } \\
\text { atau atau terbatasnya } \\
\text { tenaga SDM di bidang } \\
\text { Humas. Selama ini tenaga } \\
\text { Humas masih dipegang } \\
\text { satu orang saja yaitu Mr. } \\
\text { Ahmad Fathoni, SE. Dari } \\
\text { hasil wawancara, beliau } \\
\text { mengemukakan bahwa } \\
\text { beliau mengurusi semua } \\
\text { program yang } \\
\text { berhubungan } \\
\text { Humas. }\end{array}$ & $\begin{array}{l}\text { a. Sekolah perlu merekrut } \\
\text { anggota staf humas baru. } \\
\text { Karena jika diurus oleh } \\
\text { tenaga humas yang hanya } \\
\text { satu orang tidaklah cukup } \\
\text { mengingat pekerjaan humas } \\
\text { yang banyak. } \\
\text { b. Waka Humas } \\
\text { mengkomunikasikan } \\
\text { kebutuhannya kepada } \\
\text { kepala sekolah atau } \\
\text { pimpinan terkait dan } \\
\text { meminta kebijakan baru } \\
\text { dalam merekerut tenaga } \\
\text { kehumasan yang kompeten }\end{array}$ \\
\hline 2 & $\begin{array}{l}\text { Dalam menjalankan tugas } \\
\text { dan fungsinya, Pegawai } \\
\text { Humas kurang memiliki } \\
\text { keahlian (kompetensi). }\end{array}$ & $\begin{array}{l}\text { a. Perlu diadakan pelatihan } \\
\text { dan pengembangan skill } \\
\text { untuk tenaga kehumasan } \\
\text { dengan mengundang }\end{array}$ \\
\hline
\end{tabular}




\begin{tabular}{|c|c|c|}
\hline & $\begin{array}{l}\text { Maka perlu pelatihan } \\
\text { tenaga kehumasan atau } \\
\text { tenaga kependidikan } \\
\text { secara berkala, meliputi } \\
\text { pelatihan menjadi tenaga } \\
\text { humas yang ideal dan } \\
\text { profesional, pelatihan } \\
\text { praktis di dunia kerja, dan } \\
\text { lain-lain, pendidikan tidak } \\
\text { linier (lulusan prodi } \\
\text { ekonomi). }\end{array}$ & $\begin{array}{l}\text { praktisi luar di bidang SDM } \\
\text { atau Humas. } \\
\text { b. Dalam merekrut staf baru } \\
\text { sebaiknya mencari lulusan } \\
\text { program studi yang linier } \\
\text { (berhunungan dengan } \\
\text { humas) misal lulusan public } \\
\text { relation, psikologi, dll. } \\
\text { c. Studi banding ke sekolah } \\
\text { lain yang Humasnya sudah } \\
\text { berjalan sesuai standar atau } \\
\text { bahkan melebihi standar } \\
\text { kehumasan serta memilik } \\
\text { program humas yang } \\
\text { menginspirasi. }\end{array}$ \\
\hline 3 & $\begin{array}{lr}\text { Tumpang tindihnya } \\
\text { pekerjaan yang satu } \\
\text { dengan lainnya. Hal ini } \\
\text { disebabkan tugas Humas } \\
\text { yang merangkap tugas } \\
\text { kebersihan, } \\
\text { administrasi. dan } \\
\text { programnya tidak terfokus } \\
\text { di Humas saja. Tapi } \\
\text { selama ini Humas tidak } \\
\text { mengalami kesulitan } \\
\text { untuk menjalani itu semua } \\
\text { dengan membagi waktu } \\
\text { dan membawahi petugas } \\
\text { kebersihan. }\end{array}$ & $\begin{array}{l}\text { a. Pekerjaan humas lebih } \\
\text { difokuskan sesuai dengan } \\
\text { bidangnya. Urusan yang } \\
\text { berkaitan dengan tenaga } \\
\text { kebersihan sebaiknya } \\
\text { dikelola oleh manajemen } \\
\text { personalia (manajemen } \\
\text { pendidik dan tenaga } \\
\text { kependidikan) yakni staf } \\
\text { Personalia. } \\
\text { b. Jika staf humas terpaksa } \\
\text { turun tangan dalam } \\
\text { mengelola kebersihan, maka } \\
\text { staf humas perlu memanage } \\
\text { waktu dengan baik dan } \\
\text { tetap memprioritaskan } \\
\text { pekerjaan humas yang } \\
\text { menjadi tugas pokoknya. } \\
\text { Jangan sampai pekerjaan } \\
\text { humas kurang optimal atau } \\
\text { terbengkalai karena staf } \\
\text { humas multijob serta } \\
\text { kerepotan mengurus bidang } \\
\text { lain yang sejatinya bukan } \\
\text { garapannya }\end{array}$ \\
\hline 4 & $\begin{array}{l}\text { Tidak memiliki anggaran } \\
\text { yang memadai. }\end{array}$ & $\begin{array}{lr}\text { a. Sekolah } & \text { perlu } \\
\text { menganggarkan } & \text { khusus } \\
\text { untuk bidang humas yang }\end{array}$ \\
\hline
\end{tabular}




\begin{tabular}{|c|c|c|}
\hline & & $\begin{array}{l}\text { disepakati bersama dalam } \\
\text { forum rapat RAPBS. } \\
\text { b. Jika anggaran masih terbatas } \\
\text { juga, maka humas perlu } \\
\text { mencari alternatif dengan } \\
\text { mengusulkan sekolah untuk } \\
\text { membuka unit usaha atau } \\
\text { koperasi yang menunjang } \\
\text { kebutuhan humas dan divisi } \\
\text { lain yang membutuhkan } \\
\text { dana }\end{array}$ \\
\hline 5 & $\begin{array}{lrr}\text { Terkadang } & \text { dana yang } \\
\text { sudah } & \text { dianggarkan } \\
\text { ternyata tidak sesuai } \\
\text { dengan realita di } \\
\text { lapangan. Sehingga mau } \\
\text { tidak maur Humas } \\
\text { terkadang mengemas } \\
\text { semua kebutuhan sesuai } \\
\text { dengan yang dianggarkan } \\
\text { saja. Jika ada realita } \\
\text { anggaran kurang, bisa } \\
\text { disiasati dengan } \\
\text { mengambil alokasi sisa } \\
\text { anggaran kebutuhan lain, } \\
\text { dengan sistem silang, } \\
\text { yakni sisa anggaran lain } \\
\text { dipakai untuk menutupi } \\
\text { kekurangan yang ada. }\end{array}$ & 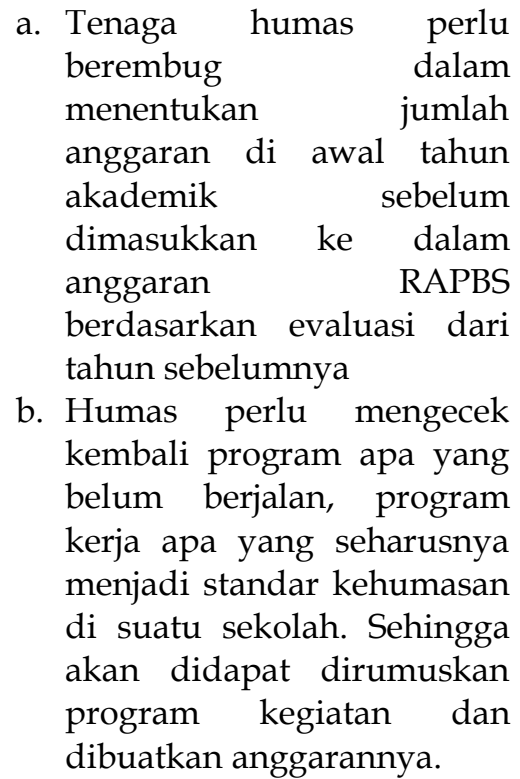 \\
\hline
\end{tabular}

\section{Kesimpulan}

Dari hasil penelitian dan pembahasan di bab sebelumnya, ditemukan berbagai permasalahan ataupun problematika dalam menjalankan manajemen kesiswaan, personalia dan humas di SD INTIS School Yogyakarta. Permasalahan dapat diringkas sebagai berikut :

Dalam manajemen Kesiswaan ditemukan permasalahan sebagai berikut :

1. Beberapa siswa tidak konsisten dalam mengikuti kegiatan ekstrakurikuler dan cenderung meminta untuk pindah ke ekstrakurikuler lain.

2. Panitia/pengurus kurang loyal pada tugas mereka

3. Masalah penyeragaman administrasi siswa

4. Jumlah agenda yang kurang didukung oleh dana yang cukup 
5. Adanya ekstrakurikuler yang kurang efektif dan tanpa bunga Dalam manajemen personalia, ditemukan masalah-masalah berikut :

1. Adanya yang mengundurkan diri setiap tahun

2. kurangnya pelatihan dan pengembangan sumber daya manusia untuk pendidik dan staf pendidikan

Sedangkan dalam masalah manajemen Humas ditemukan masalah :

1. Kurangnya staf atau atau terbatasnya sumber daya manusia di bidang Hubungan Masyarakat

2. Dalam menjalankan tugas dan fungsinya, Public Relations Karyawan kurang keahlian (kompetensi)

3. Tumpang tindih pekerjaan dengan satu sama lain

4. Tidak memiliki anggaran yang memadai

5. Terkadang dana yang telah dianggarkan ternyata tidak sesuai dengan kenyataan di lapangan

\section{Saran}

Dari permasalahan diatas, penulis memberikan alternatif pemecahan masalah sebagai berikut :

1. Manajemen kesiswaan : Waka Kesiswaan membuat kebijakan dan peraturan tentang ekskul, membagikan surat edaran pilihan ekskul, membuat target maupun capaian setiap program kerja, adanya monitoring dan evaluasi selama pelaksanaan program, menyelenggarakan AMT, dan recharging skill untuk pengurus, Pengurus sebaiknya membuat format administrasi kesiswaan yang baku dan mengarsipkannya dengan rapi, Adanya monitoring dan evaluasi pada administrasi setidaknya setiap pertengahan semester dan akhir semester, selektif dalam menyusun program kegiatan kesiswaan, Mengajukan dan menyepakati bersama anggaran dana, membuat survey tentang ekskul yang sesuai, monitoring setiap ekskul dan dievaluasi pada akhir semester

2. Manajemen Personalia : Perlu dibuatkan surat perjanjian kerja di awal untuk guru (pendidik) dan tenaga kependidikan (karyawan), Perlu dibuatkan SK Kepala Sekolah dan SK Yayasan setiap pergantian tahun akademik, Sekolah membuat buku peraturan kepegawaian, Sebaiknya diagendakan pelatihan dan pengembangan untuk guru (pendidik) maupun tenaga kependidikan (karyawan) secara rutin, Mengontrol, memonitoring dan mengevaluasi kinerja pendidik dan kependidikan 
3. Manajemen Humas : Sekolah perlu merekrut anggota staf humas baru, Waka Humas mengkomunikasikan kebutuhannya kepada kepala sekolah atau pimpinan terkait, Perlu diadakan pelatihan dan pengembangan skill untuk tenaga kehumasan, Dalam merekrut staf baru sebaiknya mencari lulusan program studi yang linier, Studi banding ke sekolah lain yang Humasnya sudah berjalan sesuai standar, Pekerjaan humas lebih difokuskan sesuai dengan bidangnya, memprioritaskan pekerjaan humas yang menjadi tugas pokoknya, menganggarkan khusus untuk bidang humas yang disepakati bersama dalam forum rapat RAPBS, Jika anggaran masih terbatas juga, maka humas perlu mencari alternatif dengan mengusulkan sekolah untuk membuka unit usaha atau koperasi yang menunjang kebutuhan humas, menentukan jumlah anggaran di awal tahun akademik sebelum dimasukkan ke dalam anggaran RAPBS berdasarkan evaluasi dari tahun sebelumnya, mengecek kembali program apa yang belum berjalan, program kerja apa yang seharusnya menjadi standar kehumasan di suatu sekolah. 


\section{Daftar Pustaka}

Baharuddin. dan Makin, Moh. Manajemen Pendidikan Islam, Transformasi menuju sekolah/madrasah unggul. Malang : UIN-Maliki Press. 2010

Moleong, Lexy J. Metodologi Penelitian Kualitatif. Bandung : PT Remaja Rosdakarya. 2007.

Pidarta, Made. Manajemen Pendidikan Indonesia. Jakarta : Rineka Cipta. 2004.

Mardalis. Metodologi Penelitian Suatu Pendekatan Proposal. Jakarta : Bumi Aksara. 2008.

Rohman, Muhammad. dan Amri, Sofan. Manajemen pendidikan. Jakarta : PT Prestasi Pustkaraya. 2012.

Qomar, Mujamil. Manajemen Pendidikan Islam. Jakarta : Erlangga. 2007.

Mulyasa. Manajemen Berbasis Sekolah, Konsep Strategi dan Implementasi. Bandung : PT Remaja Rosdakarya. 2003.

Sukmadinata, Nana Syaodih. Metode Penelitian Pendidikan. Bandung : PT Remaja Rosdakarya. 2008.

Sugiyono. Metode Penelitian Pendidikan, Pendekatan Kuantitatif, Kualitatif, dan RED. Cet. VII. Bandung : Alfabeta, 2009.

Arikunto, Suharsimi. dan Yuliana, Lia. Manajemen Pendidikan. Yogyakarta : Graha Cendekia bekerja sama dengan Pujangga Press. Tanpa tahun.

Suryosubroto. Manajemen Pendidikan di Sekolah. Jakarta : Rineka Cipta. 2010. 